University for Business and Technology in Kosovo

UBT Knowledge Center

UBT International Conference

2018 UBT International Conference

Oct 27th, 3:15 PM - 4:45 PM

\title{
Determination of Control Parametres of Land and Economic Development of the Region of Struga
}

\author{
Suzana Aliu \\ University for Business and Technology \\ Fidan Feka \\ University for Business and Technology \\ Hyzer Rizani \\ University for Business and Technology \\ Fisnik Laha \\ University for Business and Technology, fisnik.laha@ubt-uni.net \\ Valon Durguti \\ University for Business and Technology
}

Follow this and additional works at: https://knowledgecenter.ubt-uni.net/conference

Part of the Food Science Commons

\section{Recommended Citation}

Aliu, Suzana; Feka, Fidan; Rizani, Hyzer; Laha, Fisnik; and Durguti, Valon, "Determination of Control Parametres of Land and Economic Development of the Region of Struga" (2018). UBT International Conference. 163.

https://knowledgecenter.ubt-uni.net/conference/2018/all-events/163

This Event is brought to you for free and open access by the Publication and Journals at UBT Knowledge Center. It has been accepted for inclusion in UBT International Conference by an authorized administrator of UBT Knowledge Center. For more information, please contact knowledge.center@ubt-uni.net. 


\title{
Determination of Control Parameters of Land and Economic Development of the Region of Struga
}

\author{
Suzana Aliu, Hyzer Rizani, Valon Durguti, Fidan Feka, Fisnik Laha, \\ suzana.aliu@ubt-uni.net
}

\begin{abstract}
Problem statement: Defining the control parameters of land, before that it be used to plant a culture is an important for the economic development of that region. Aproch: This paper treats the economical development for the quality of the land. Object of this study is determination of control parameters in land of Struga Region like Humus, $\mathrm{pH}$-value, CaCO3, K2O, P2O5, total Azot.. Results: The results that were achieved in this study showed the significant difference in the quality of land . Indication for this are the smoll value of $\mathrm{K} 2 \mathrm{O}$ which results goes from $4.81 \mathrm{mg} / 100 \mathrm{~g}$ land to $15.22 \mathrm{mg} / 100 \mathrm{~g}$ land. Conclusion/Recommendations: For sowing potato culture or sun flower is necessary to preliminarily treated with organic fertilizers.
\end{abstract}

Keywords: determination, organic fertilizers, economic development.

\section{Introduction}

The land where we live and develop our activities is very important for our lifes. Just like water and air, the land is threatened by pollution.

Earth threatment for loss of upper layer, comes from the development of human agriculture and livestock. Its loss comes from the phenomenon of deforestation, erosion,. changing temperatures etc.

Land's crust is characterized by the presence of many nature organic or inorganic compounds. The introduction of pollutants in one ecosystem is of a particular importance due to the preservation of dynamic balance in the ecosystem. As, the crust of the Land is an open system, knowledge about any pollutant, from any source and any amount is of a high, worth and importance.

\section{Economic development of the region of Struga}

Struga Town is located on the north shore of Lake Ohrid. The Drini I Zi River flows through the heart of the city after it journeys from the springs near St. Naum through Lake Ohrid. The climate in Struga is temperate - continental, and it's determined by the complex relief structure depending on the height above the sea level, as well as by the penetration of the climate effects of the Adriatic Sea from the west, all the way through the river Drini I Zi and the climate effects of the Ohrid Lake, functioning as climate modifications.

Sustainable Development Strategy has three main objectives:

- Economic development

- Equality and social cohesion

- Environmental protection 
For economic development in Region of Struga it is necessary bringing and application of rigorous juridical orders and rules with international and national character.

Growth of cooperation between governmental and non-governmental organizations.

Cooperation of organs of central government (ministry) with organs of local government and cooperation of units of local self-government (Commune) between them and cooperation with Non-governmental organizations.
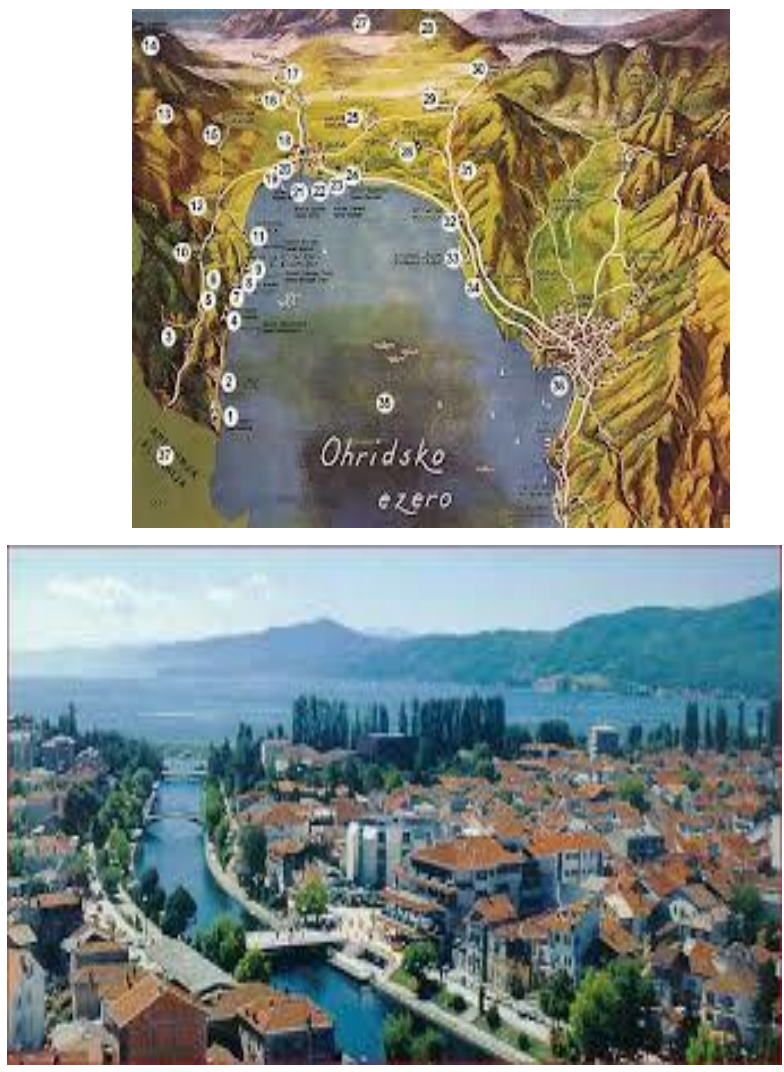


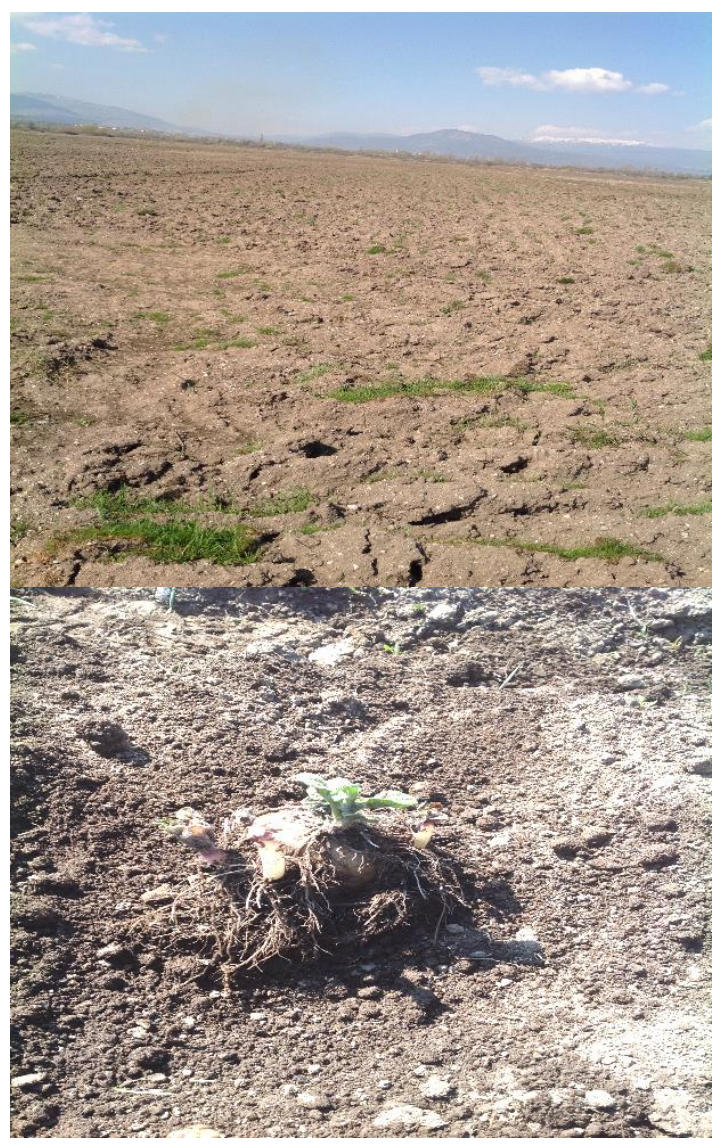

\section{Experimental engagement, material gathering and working methods}

The material Gathering was done during a spring 2017/2018. Object of this study is determination of control parameters in land of Struga Region like $\mathrm{pH}$-value, Humus, $\mathrm{CaCO} 3, \mathrm{~K} 2 \mathrm{O}$, P2O5, total Azot. This samples were taken in two different locations with $10 \mathrm{Ha}$ land each. In the first $10 \mathrm{Ha}$ the land is prepared for planting potatoes. The $2^{\text {nd }} 10 \mathrm{Ha}$ of land is being prepared for planting sunflowers.

To achieve this, $\mathrm{pH}$ - value is done with electrometric method with the help of the glass electrode, Hummus is defined with Kotzman method, the amount of carbonates is done with volumetric method, amount of potassium, $\mathrm{K} 2 \mathrm{O}$ and phosphorus $\mathrm{P} 2 \mathrm{O} 5$ are done with $\mathrm{Al}$ method, total amount of nitrogen is calculated. 


\section{Experimental results}

Achieved results are given in table and graphic form. Tables represent the achieved experimental results of control pollution parameters in the studied samples as well as concentration of the $\mathrm{pH}$ -value, Humus, $\mathrm{CaCO} 3, \mathrm{~K} 2 \mathrm{O}, \mathrm{P} 2 \mathrm{O} 5$, total Nitrogen.

Tab. 1 - Determination of control paramethers of land for planting potatoes

\begin{tabular}{|c|c|c|c|c|c|c|c|}
\hline Sample & $\begin{array}{c}\text { Depth } \\
\text { cm }\end{array}$ & $\begin{array}{c}\text { Hummus } \\
\%\end{array}$ & $\begin{array}{l}N \\
\%\end{array}$ & $\begin{array}{c}\mathrm{CaCO} 3 \\
\%\end{array}$ & $\begin{array}{c}p H \\
\\
\quad \mathrm{H} 2 \mathrm{O} \\
N \quad \mathrm{KCl}\end{array}$ & $\begin{array}{c}P 205 \\
m g / \\
100 \mathrm{~g}\end{array}$ & $\begin{array}{l}\mathrm{K} 20 \\
\mathrm{mg} / \\
100 \mathrm{~g}\end{array}$ \\
\hline$\underline{1}$ & $0-30$ & 4.84 & 0.29 & 0.00 & $\begin{array}{l}6.05 \\
5.07\end{array}$ & 5.93 & 7.21 \\
\hline$\underline{2}$ & $0-30$ & 4.78 & 0.29 & 0.00 & $\begin{array}{l}7.53 \\
6.98\end{array}$ & 5.51 & 6.01 \\
\hline$\underline{3}$ & $0-30$ & 4.86 & 0.29 & 0.00 & $\begin{array}{l}7.47 \\
7.00\end{array}$ & 11.43 & 5.61 \\
\hline$\underline{4}$ & $0-30$ & 4.89 & 0.29 & 0.00 & $\begin{array}{l}6.27 \\
5.70 \\
\end{array}$ & 4.66 & 5.61 \\
\hline$\underline{5}$ & $0-30$ & 4.80 & 0.29 & 0.00 & $\begin{array}{l}6.67 \\
6.01\end{array}$ & 6.56 & 4.01 \\
\hline$\underline{6}$ & $0-30$ & 4.82 & 0.29 & 0.00 & $\begin{array}{l}6.59 \\
5.99\end{array}$ & 9.53 & 5.61 \\
\hline 7 & $0-30$ & 4.90 & 0.29 & 0.00 & $\begin{array}{l}6.07 \\
5.45\end{array}$ & 20.33 & 8.81 \\
\hline Average & $0-30$ & 4,84 & 0.29 & 0.00 & $\begin{array}{l}6.67 \\
6.02\end{array}$ & 9.14 & 6.12 \\
\hline
\end{tabular}

Tab. 2 - Determination of control paramethers of land for planting sunflowers

\begin{tabular}{|c|c|c|c|c|c|c|c|}
\hline Sample & $\begin{array}{c}\text { Depth } \\
\text { cm }\end{array}$ & $\begin{array}{c}\text { Hummus } \\
\%\end{array}$ & $\begin{array}{l}N \\
\%\end{array}$ & $\begin{array}{c}\mathrm{CaCO3} \\
\%\end{array}$ & 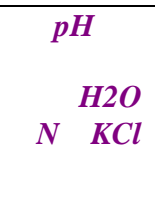 & $\begin{array}{c}P 205 \\
m g / \\
100 g\end{array}$ & $\begin{array}{l}\mathrm{K} 2 \mathrm{O} \\
\mathrm{mg} / \\
100 \mathrm{~g}\end{array}$ \\
\hline$\underline{1}$ & $0-30$ & 5.10 & 0.31 & 0.00 & $\begin{array}{l}6.26 \\
5.50\end{array}$ & 11.43 & 5.61 \\
\hline$\underline{2}$ & $0-30$ & 5.05 & 0.30 & 0.00 & $\begin{array}{l}6.16 \\
5.51\end{array}$ & 16.52 & 6.01 \\
\hline$\underline{3}$ & $0-30$ & 5.07 & 0.30 & 0.00 & $\begin{array}{l}5.92 \\
5.09\end{array}$ & 21.60 & 6.01 \\
\hline$\underline{4}$ & $0-30$ & 5.09 & 0.31 & 0.00 & $\begin{array}{l}5.95 \\
5.12\end{array}$ & 13.76 & 5.61 \\
\hline$\underline{5}$ & $0-30$ & 5.02 & 0.30 & 0.00 & $\begin{array}{l}6.31 \\
5.70\end{array}$ & 19.48 & 5.61 \\
\hline
\end{tabular}




\begin{tabular}{|c|l|l|l|l|l|c|c|}
\hline$\underline{6}$ & $0-30$ & 5.03 & 0.30 & 0.00 & $\begin{array}{l}5.25 \\
4.89\end{array}$ & 16.09 & 17.62 \\
\hline$\underline{7}$ & $0-30$ & 5.07 & 0.30 & 0.00 & $\begin{array}{l}5.57 \\
4.92\end{array}$ & 16.09 & 6.41 \\
\hline 8 & $0-30$ & 5.06 & 0.30 & 0.00 & $\begin{array}{l}5.64 \\
4.96\end{array}$ & 17.36 & 8.01 \\
\hline 9 & $0-30$ & 5.07 & 0.30 & 0.00 & $\begin{array}{l}5.62 \\
4.97\end{array}$ & 18.21 & 6.01 \\
\hline 10 & $0-30$ & 5.04 & 0.30 & 0.00 & $\begin{array}{l}5.90 \\
5.03\end{array}$ & 30.49 & 6.01 \\
\hline 11 & $0-30$ & 5.02 & 0.30 & 0.00 & $\begin{array}{l}7.41 \\
6.75\end{array}$ & 21.39 & 8.81 \\
\hline 12 & $0-30$ & 5.09 & 0.31 & 0.00 & $\begin{array}{l}7.24 \\
6.70\end{array}$ & 16.30 & 7.61 \\
\hline 13 & $0-30$ & 5.05 & 0.30 & 0.00 & $\begin{array}{l}7.57 \\
6.77\end{array}$ & 12.49 & 6.81 \\
\hline 14 & $0-30$ & 5.04 & 0.30 & 0.00 & $\begin{array}{l}6.77 \\
6.02\end{array}$ & 13.13 & 8.01 \\
\hline Average & $0-30$ & 5.05 & 0.30 & 0.00 & $\begin{array}{l}6.25 \\
5.56\end{array}$ & 17.45 & 8.01 \\
\hline
\end{tabular}
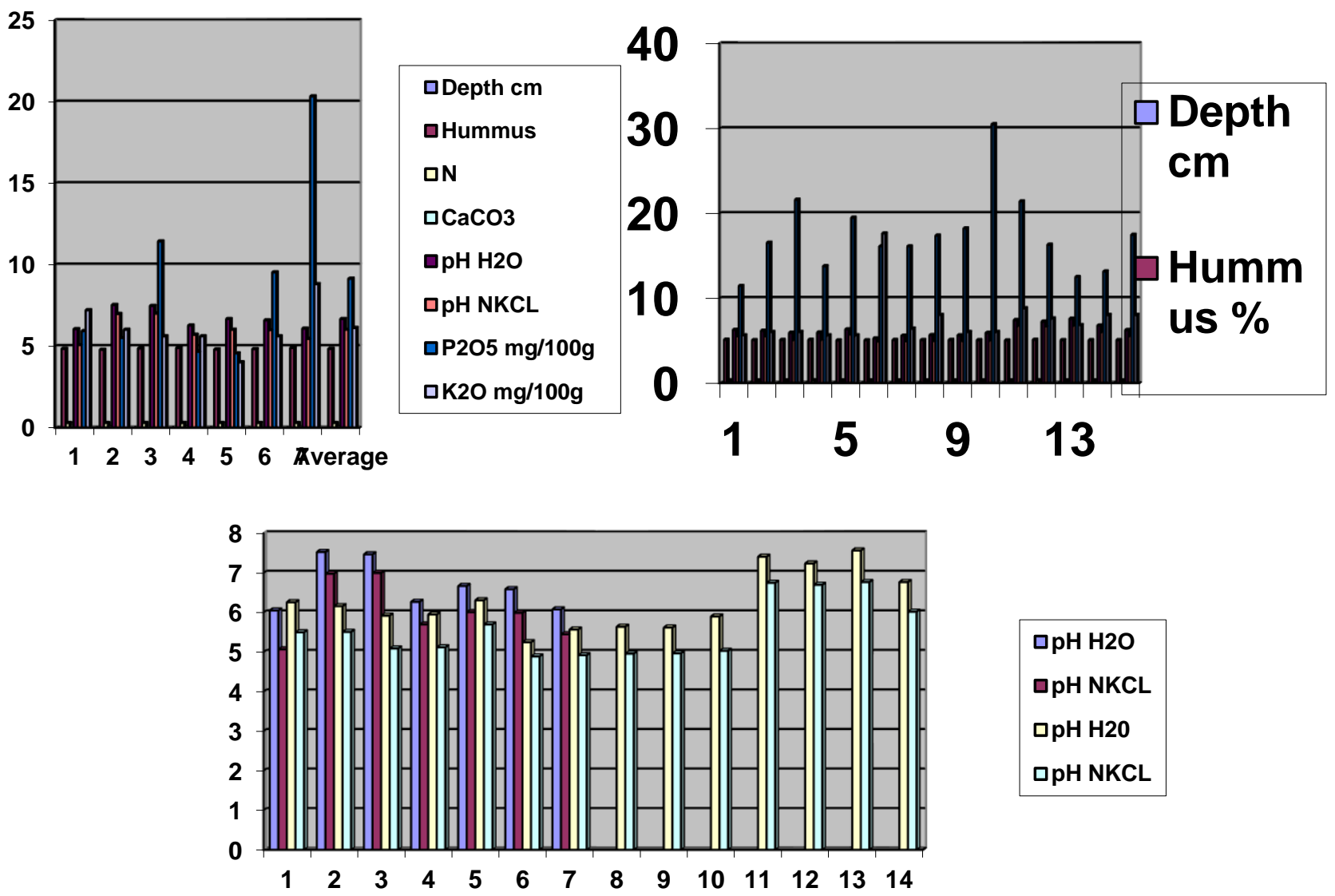

口pH H2O

口pH NKCL

口pH H2O

口pH NKCL 

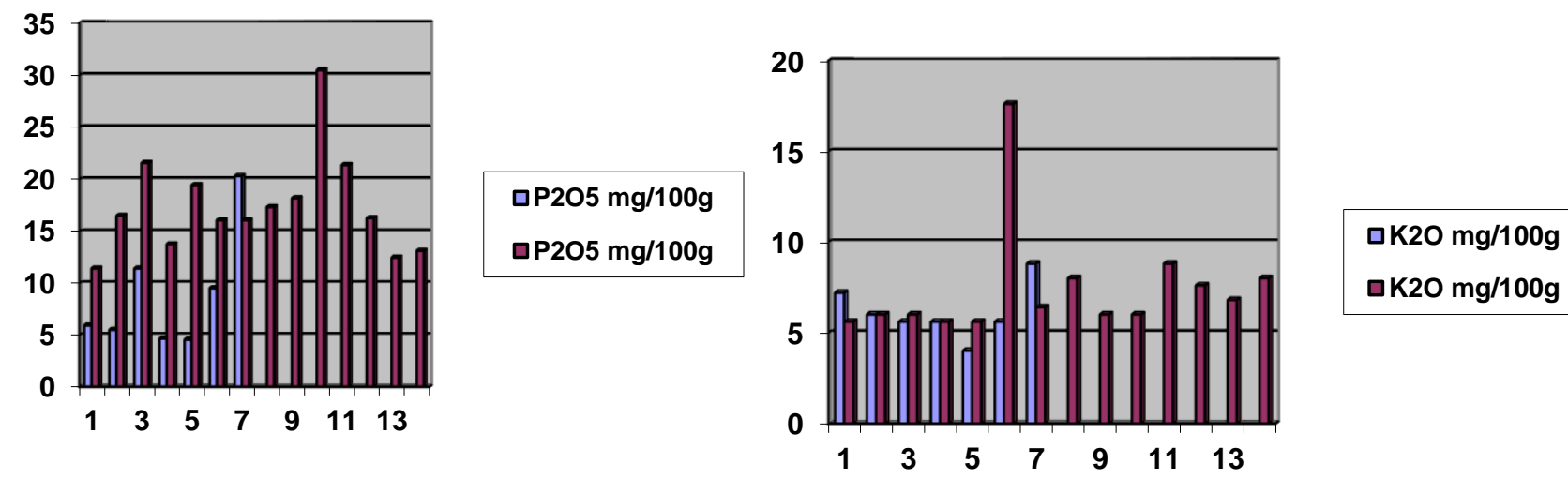

\section{Discussion of results}

The concentration of hummus during our study was as follows:

- Minimal amount of humus $4.73 \%$. and maximal amount $5.1 \%$.

- $\quad$ For azot we have minimal value $2.9 \%$ and maximal value $0.31 \%$.

- In the our stady land, we have not concentration of calcium carbonates.

- $\mathrm{pH}$ value is 5.07 and maximal value of $\mathrm{pH}$ is 7.57.

- The concentration of $\mathrm{KCl}$ in the study samples are 5.07 minimal value and 6.98 maximal value.

- $\mathrm{P} 2 \mathrm{O} 5$ is represented with minimal concentration $5.93 \mathrm{mg} / 100 \mathrm{~g}$ and $30.49 \mathrm{mg} / 100 \mathrm{~g}$ maximal concentration.

- $\mathrm{K} 2 \mathrm{O}$ has given following results: $4.01 \mathrm{mg} / 100 \mathrm{~g}$ minimal value and $17.62 \mathrm{mg} / 100 \mathrm{~g}$ maximal

\section{Conclusions}

Regarding our results from our analyses we can conclude that:

Analyzed samples of land are acidik or neutral, becouse $\mathrm{pH}$ value is 5.07 and maximal value of $\mathrm{pH}$ is 7.57 .

Humus is the most important factor of land's fertility. Humus affects physical, chemical and biological attributes of land. Humus has adhesive effects on creation of macro aggregates. With Its dark color affects soil heating and reduces erosion. In chemical terms, Humus adjusts 
nutritional substances in land. Adsorption capacitiy is 2-3 times better than clay. Our results say that land is rich with humus and belongs to humus - rich soils.

Reactions on soil are very important for vital functions of plant.

Organic part of Nitrogen can be found in humus and in indissoluble plant or animal remains. The overall amount of Nitrogen in agricultural lands ranges 0.1-0.3\%. For plant feeding on vegetation period that value ranges $1-3 \%$. Therefore fertilization with nitrogen fertilizers in modern production activities is necessary. Regarding our results nitrogen fertilizers should be added, because the land can be classified as nitrogen - poor soil.

Phosphorus role is, consisting in many processes. Plants use only in its oxidized form, like ortophosphoric acid. Regarding our analyses this land has average levels of phosphorus and should be treated.

Potassium isn't directly included in composition of organic compounds or enzymes, but affects synthesis of cellulose, affects the change of osmotic pressure and is being used in ionic form. This land belongs to poor - potassium soil and should be supplied with it. K2O has given following results: $4.01 \mathrm{mg} / 100 \mathrm{~g}$ minimal value and $17.62 \mathrm{mg} / 100 \mathrm{~g}$ maximal value. In order to obtain high efficiency this land should be treated with fertilizers like $25 \% \mathrm{~K}: 15 \% \mathrm{P}: 5 \% \mathrm{~N}$, and the expected yield of potatoes will be 35 tons per hectar, or could be used for planting sunflowers culture, but always counting on favorable climatic conditions, which is characteristic for this region.

\section{References}

1. Catherine L. Kling, Kathleen Segerson and Jason F. Shogren "Environmental Economics: How Agricultural Economists Helped Advance the Field" American Journal of Agricultural Economics, v. 92(2010)., pp. 487-505.

2. Heathcote Aj, Filstrup Ct, Downing Ja Watershed Sediment Losses To Lakes Accelerating Despite Agricultural Soil Conservation Efforts. (2013) Plos One 8: E53554. Li S, Gu S, Liu W, Han H, Zhang Q Water Quality In Relation To Land Use And Land Cover In The Upper Han River Basin, China. Catena 75: (2008) pp 216222.

3. National Rural Parliament as a voice of rural citizens. "Project is funded by the European Union” E - Bulletin no.16 July 2018.

4. Kolovos A, Christakos G, Serre Ml, Miller Ct Computational Bayesian Maximum Entropy Solution Of A Stochastic Advection - Reaction Equation In The Light Of Site - Specific Information. Water Resour (2002). Pp. 38: 51-54. 